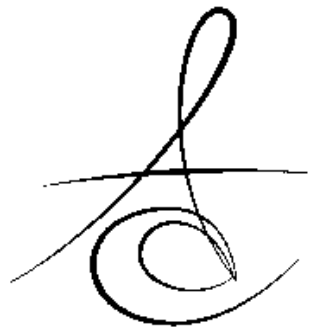

\title{
SQUAMOUS HÜCRELİ KARSİNOM GELIŞ̧EN EPİDERMOLİZİS BÜLLOZA VE DENTAL TEDAVİ YAKLAŞIMLARI
}

\section{EPIDERMOLYSIS BULLOSA WITH SQUAMOUS CELL CARCINOMA DENTAL TREATMENT APPROACH}

\author{
Dr. Özlem FİLİZ BAYAR*
}

Prof. Dr. Gülsüm AK*

Makale Kodu/Article code: 2080

Makale Gönderilme tarihi: 21.01.2015

Kabul Tarihi: 09.04.2015

\section{ÖZET}

Epidermolizis Bülloza (EB) deri ve mukozalarda frajilite artışına bağlı olarak minör travmalar sonucu tekrarlayııı mekanik bül oluşumu ve erozyon ile karakterize, nadir görülen otozomal dominant veya resesif geçişli bir hastalıktır. Bu çalışmada, sağ kolunda squamous hücreli karsinom gelişen distrofik epidermolizis bülloza hastamı nedeniyle güncel literatür derlemesiyle birlikte dental tedavi yaklaşımlarını sunmaktayız. Bu çalışmayla EB hastalarında diş tedavisinin güçlükleri ve özel teknikleri anlatılarak, diş hekimleri ve uzmanların bu teknikleri benimsemesi, güvenli ve etkili tedavi yöntemleri ile koruyucu-önleyici yaklaşımları uygulaması amaçlanmıştır.

Anahtar Kelimeler: Epidermolizis bülloza, dental tedavi yaklaşımı, squamous hücreli karsinom

\section{GİRIŞ}

Epidermolizis bülloza (EB) nadir görülen otozomal dominant veya resesif geçişli bir hastalıktır . Deri ve mukozalarda frajilite artışına bağ Iı olarak minör travmalar sonucu tekrarlayıcı mekanik bül oluşumu ve erozyon ile karakterize çok sayıda bozukluğu içine alan bir grup hastalıktır. Bül oluşumu epidermis veya bazal membranda (dermopidermal bileşke) bulunan proteinleri kodlayan genlerdeki mutasyonlar sonucu gelişir . Hastaların büyük bir çoğunluğunda bulgular doğumda veya doğumdan kısa bir süre sonra ortaya çıkarken hafif formlar çocukluk dönemine veya erken erişkin döneme kadar bulgu vermeyebilir. ${ }^{1-3}$

1962'de Pearson elektron mikroskopik yöntem lere dayanarak EB'yı üç büyük fenotipik gruba ayır mıştır. Bunlar sırasıyla EB simpleks (EBS), junctional EB (JEB), distrofik EB (DEB)'dır. Daha sonra 2007'de

\section{ABSTRACT}

Epidermolysis bullosa (EB), refers to rare autosomal dominant or recessive disorder, characterized by fagility of the skin and mucous membranes, and blister formation in response to minor friction or trauma. The aim of this article is to describe dental clinical treatments of dystrophic EB case with squamous cell carcinoma his arm and his specific clinical manifestations with current litterateur. This article describes the phases and difficulties of dental treatment and the measures that dentists and health care providers should adopt in order to provide a safe and effective dental treatment as well as earlier prevention to these patients.

Key Words: Epidermolysis Bullosa, Dental Treatment Approach, Squamous Cell Carcinoma

yeni sınıflama yapılmış ve EB dört ana gruba ayrılarak Kindler Sendromu da sınıflamaya eklenmiştir. Epidermolizis bülloza kalıtsal geçişin şekline, büllerin ayrışma seviyesine, lezyonların klinik ve morfolojik özelliklerine, hastalığın yaygın ya da sınırlı oluşuna ve deri dışı komplikasyonların varlığına gö re sınıflandırılır. Olguların \%92'si EBS, \%5'i DEB, \%1'i JEB ve \%2'si sınıflanamayan tip olarak bildirilmektedir. Junctional ve distrofik tipler gibi şiddetli EB formlarına belirgin morbiti deye yol açan deri dışı komplikasyonlar eşlik edebilir . 4-6 $^{-6}$

* İstanbul Üniversitesi, Diş Hekimliği Fekültesi, Ağız Diş ve Çene Cerrahisi Anabilim Dalı 
Tablo 1. Epidermolizis bülloza sınıflaması ${ }^{(3)}$

\begin{tabular}{|l|l|l|l|}
\hline \multicolumn{4}{|l|}{ Tablo 1. Epidermolizis büllozanın sınflaması } \\
\hline Tip & & Bül lokalizasyonu & Mutasyon \\
\hline EB simpleks & $\begin{array}{l}\text { Intraepidermal } \\
\text { (Epidermolitik) }\end{array}$ & Intraepidermal & $\begin{array}{l}\text { KRT5,KRT14, } \\
\text { Plectin, } \alpha 6 B 4, \\
\text { Plakofilin1, } \\
\text { dezmoplakin }\end{array}$ \\
\hline "Junctional" EB & Lamina lucidolitik & Intra-Lamina lusida & $\begin{array}{l}\text { Laminin332, } \\
\alpha 6 B 4 \text { integrin, } \\
\text { Tip17 kollajen }\end{array}$ \\
\hline Distrofik EB & Dermolitik & Sub-lamina densa & Kollajen 7 \\
\hline Kindler sendromu & Miks & Miks & Kindlin \\
\hline
\end{tabular}

\section{Epidermolizis Bülloza Çeşitleri}

1. Epidermolizis Bülloza Simpleks (EBS)

Epidermolizis Bülloza Simpleks (EBS) en sık görülen tipi olup görülme sıklığı yaklaşık bir milyon canlı doğumda 6-30 olduğu tahmin edilmektedir EBS'in bütün formları mekanik sürtünme ve travma sonucu büllerin oluşumu ile karakterizedir . Keratoderma, tırnak ditrofisi, alopesi ve mukozal tutulum daha nadirdir. Sadece nadir görülen 3 alt-tip dışında hepsinde büll er epidermisin bazal tabakasında oluşur . Skar oluşumu, milia ve tırnak distrofisi JEB ve DEB'ye göre daha azdır . Erozyonlar ve büller skar olmaksızın hiperpigmentasyonla iyileşir. EB nevusu, EB'nın major formlarının hepsinde görülür . Klinik ve dermoskopik olarak melanomaya benzese de malign transformasyon olmadan spontan olarak gerilediği bildirilmektedir . EBS'de hastalık aktivitesi genellikle doğumda veya hemen sonra başlar ancak daha az şiddetli olgularda hastalığın ortaya çıkışı ikinci v eya üçüncü dekatta ol maktadır. Yaşla birlikte hastalıkta gerileme olabil mektedir. Sıcakla ve terleme ile lezyonlarda artış görülebilir. . $^{6-8}$

\section{Junctional Epidermolizis Bülloza (JEB)}

Dermo-epidermal bileşkenin lamina lusidasında ayrışma ile karakterize otozomal resesif kalıtılan mekanobüllöz bozukluktur . Bu grup bozukluklar hayatı tehdit eden şiddetli hastalıktan nispeten daha hafif formları içeren bir spektruma sahiptir . JEB tiplerinde en karakteristik klinik bulgu diş minesi hipoplazisidir . Dişlerin bazılarında veya hepsinde yüzey de lokalize ya da yaygın yüksük benzeri pitting vardır. ${ }^{5}$

\section{Distrofik Epidermolizis Bülloza (DEB)}

Dominant ve resesif olmak üzere iki formu mevcuttur. Dominant hastalıkta bulgular resesif forma göre daha hafiftir. Etkilenen bireyler genellikle sağlıkı, normal yapıdadır . Bül oluşumu sınırıdır . Elektron mikroskopik inceleme ; ayrımanın dermoepidermal bileşkenin dermal yüzünde, bazal laminada olduğunu ve hem normal hemde büllü deride anchoring fibrillerin olmadığını yada azaldığını gösterir . DEB'da genellikle bül, erozyon, atrofik skar , milia oluşumu , tırnak distrofisi, tırnak yokluğu gibi bulgular gözlenir. ${ }^{9}$

\section{Kindler Sendromu}

EB'nın spesifik bir formudur. Travma ile oluşan büllerin yerinde gelişen progr esif atrofi ve poikilodermi ile karakterizedir. Doğumda başlar. Deri bulguları arasında travmatik akral bül oluşumu, deri frajilitesi, el ve ayak parmakları arasında perdelenme , daha sonraki dönemlerde poikilodermik pigmentasyon ve hafif bir güneş maruziyeti sonrasında bile gelişebilen fotosen sitivite mevcuttur. Patogenezinde altta yatan patolojinin ekstraselüler matriks proteinlerinden aktinle ilişkili olduğu düşünülmektedir. ${ }^{10,11}$

\section{Deri Dışı Komplikasyonlar}

Epidermolizis büllozanın birçok tipinde, morbiditeye ve bazı olgularda ölüme yol açan deri dışı komp likasyonları mevcuttur. Bunlar şu şekilde sıralanabilir:

- Malnutrisyon

- Anemi

- Enfeksiyon

- Büyüme geriliği ve pubertede gecikme

- Osteopeni/Osteoporoz

- Oral mukoza komplikasyonları (Tekrarlayan büller sonucu oluşan skar nedeniyle mikrostomi, ankiloglossi, dilde atrofi, vestibül sulkusda daralma, oral kanserler görülebilir.)

- Oküler komplikasyonlar

- Tirnak distrofisi

- GIS komplikasyonlar

- GUS komplikasyonları

- Üst solunum yolları komplikasyonları

- Muskuloskeletal komplikasyonlar

- Kardiyomiyopati

- Squamous hücreli karsinom ve malign melanoma gelişebilir. Özellikle distrofik tip EB'de kronik sikatris alanlarında squamous hücreli karsinom gelişme riski yüksektir. ${ }^{12,13}$

\section{Teşhis}

Işık mikroskopi, immünfloresan antijenik haritalama, transmisyon elektron mikroskopisi , mutasyon analizi başııca tanı yöntemleridir..$^{14,15}$

\section{Tedavi}

Kesin bir tedavisi olmayıp palyatif tedavi yöntemleri uygulanır. Tedavide amaç öncelikle yeni bül

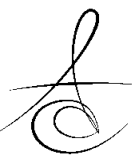


oluşumunu önlemek için travmadan kaçınmak , sekonder enfeksiyonları önlemek, yara iyileştirmesini hızlan dırmak ve nutrisyonel destek sağlamaktır . Bu nedenle hasta ve hasta yakınları travmadan kaçınmak ve yara bakımı konusunda eğitilmelidir. ${ }^{3}$

Ülser ve erozyonların günlük bakımı yapılmalı dır. Yeni çıkan büllerin steril olarak patlatılması gerekir . Ayrıca yara iyileşmesini hızlandıran kapatıcı yara örtüleri kullanılmalıdır. Enfeksiyon ve skar oluşumu gibi komplikasyonların önlenmesi ve tedavi edi Imesi gerekmektedir. Enfeksiyonun önlenmesi için antibiyotik içeren krem veya pomadlar kullanılabilir . Tetrasiklinin kollejenazı inhibe ederek bül oluşumunu azalttığı bilinmektedir. Zaman zaman sistemik antibiyotik gereksinimi olabilir . Ülser ve erozyonların bakımı sırasında ağrının kontrol edilmesi gerekir. 2,6,7

Topikal ya da sistemik kortikosteroid kulanımıyla kalıcı bir tedavi sağlanamamıştır. Sistemik A vitamini kullanımı bülleri bir miktar azaltmaktadır ancak bunun etki mekanizması bilinmemektedir. E vitamini kulanımının bazı hastalarda faydalı olduğu rapor edilmiştir. Fenitoin tedavisi dermal fibroblastlarla kollejenazın sentez ve salınımını önleyerek bül oluşumunu azalttığı bildirilmiştir. ${ }^{16}$

Ellerdeki deformitelerin ve kontraktürlerin düzeltilmesi için cerrahi tedavi gerekli olabilir . Kronik iyileşmeyen ülserlere deri grefti uygulanabilir ${ }^{17}$ Ayrıca EB'lı hastalarda deri dışı komplikasyonların saptanması ve tedavi edilmesi gerekir. ${ }^{2,6,7}$

\section{Oral Bulgular}

Dil, bukkal mukoza, damak, ağız tabanı ve gingiva hastalıktan etkilenir. ${ }^{18}$ Oral bölgede en sık görülen bulgu büllerdir. Tekrarlayan büller skar oluşumuna neden olarak mikrostomi, ankiloglossi, dilde atrofi ve oral vestibülün ortadan kalkmasına neden olur. Damakta oral milia (Genellikle ağız tabanında olan fibrin dolu küçük kistler) görülür. Dişlerde defektli mine ve yaygın atipik çürükler görülebilir. Mikrostomi nedeniyle ağız açma kısıtlıdır. Ciddi periodontal hastalık ve oral kanserler görülebilir. ${ }^{19}$

\section{Stratejisi}

Epidermolizis Büllozada Dental Tedavi

EB hastalarının dental tedavisinde özel protokoller uygulanmaktadır. Öncelikle EB hastalarında koruyucu-önleyici yöntemler mutlaka uygulanmalıdır. Hastaların ilk diş hekimine yönlendirilmesi doğumdan sonra 3-6 aylıkken olmalıdır. Hastanın ailesi ağız bakımı konusunda eğitilmeli, diş fırçalama alışkanlığı mutlaka edindirilmelidir. Bu hastalarda mikrostomi olduğu için küçük başlı, yumuşak ve kısa kıllı diş fırçaları tercih edilmelidir. Diş hekimleri tarafından profesyonel hijyen uygulamaları yapılırken yumuşak ve dikkatli teknikler kullanılmalıdır. Yüksek çürük riski grubundaki hastalara topikal florid uygulanmalıdır. Mikrostomia olan hastalarda günlük ağız açma-kapama egzersizleri verilmelidir. EB hastalarına ilaç reçete edilirken özefagal darlık olabileceği için ilaçların likit formları tercih edilmeli ve ilaçlar şekersiz olmalıdır. Bu hastalar çürük açısından risk grubunda oldukları için her 3-6 ayda bir diş hekimi kontrolü gereklidir. EB hastalarında oral squamous hücreli karsinom gelişme riski yaşla birlikte artmaktadır. Özellikle 2. dekattan sonra bu hastalar dikkatle takip edilmelidir. ${ }^{20}$

EB hastalarından röntgen almak gerektiğinde periapikal röntgen yerine panoromik röntgen tercih edilmelidir. Periapikal rötgeni özellikle mikrostomisi olan hastalarda posterior bölgeden almak çok zordur. Ayrıca periapikal röntgen ağız içinde lingual bölgede basınç oluşturabileceği için tercih edilmemelidir. ${ }^{20}$

EB hastalarında dental tedaviler bazı önlemler alınarak yapılabilir. Tedaviye başlamadan önce hastanın dudaklarına vazelin gibi bir lubrikant sürülmelidir. Böylece lezyon oluşma riski en aza indirilir. Tükürük emici tipine ve kullanım şekline dikkat edilmelidir. Oral mukozada kolayca bül oluşabildiğinden tükürük emici en düşük seviyede kullanılmalı ve yumuşak dokuya mümkün olduğunca temas etmeyerek diş yüzeylerinde tutulmalıdır. Tedavi sırasında kolayca bül oluşabilir. Bu büller steril bir şekilde patlatılmalıdır. Dokular çok frajil olduğu için en ufak bir baskı yapmaktan kaçınılmalıdır. El aletleriyle mümkün olduğunca baskı yapmadan, çok nazik çalışılmalıdır. ${ }^{20}$

$\mathrm{Bu}$ prensiplere dikkat ederek EB hastalarında her türlü restoratif ve endodontik tedavi yapılabilir. Aneztezi yüzeyel değil derin dokuya yapılmalı ve anestezik madde yavaş verilmelidir. Protez yapmak gerektiğinde sabit protezler tercih edilmelidir. Mine hipoplazisi görülen hastalar kuronla restore edilebilir. Cerrahi çekimler minimum travmayla yapılmalıdır ve hemostaz sağlarken fazla basınç uygulanmamalıdır. Seri çekimler gerekliyse hastanın doktoru ile konsülte edilmelidir, çünkü hastalar anemik olduğu için komplikasyon gelişebilir. Gerekli ise sutur atılabilir ancak sutur atarken dokular frajil olduğundan çok nazik olunmalı ve travma oluşturmaması için suturun yerleşimine dikkat edilmelidir. Protez yapılırken kısa ark 
tercih edilmek koşuluyla dental implantlar EB hastalarına uygulanabilir. ${ }^{20}$

\section{SQUAMOUS HÜCRELİ KARSİNOM GELIŞEN EPİDERMOLİZİS BÜLLOZA OLGUSU}

25 yaşında erkek hasta alt çene sol kanin dişi hizasında ekstraoral abse şikayetiyle İ.Ü. Ağız, Diş ve Çene Cerrahisi Anabilim Dalı'na başvurdu. Hastadan alınan anamnezde Distrofik tip Epidermolizis Bülloza tanısıyla İ.Ü. Tıp Fakültesi Dermatoloji Anabilim Dalı'nda takibinin devam ettiği öğrenildi. Hastanın doğumundan sonra dudak çevresinde soyulma şeklinde ilk belirtiler görülmüş. Daha sonra ayak tabanları, kollar ve ellerde travma yerlerinde büller oluşmuş. 8-9 yaşına geldiğinde ellerde sikatrisler oluşmuş, tekrarlayan büller ve sikatrisler sonucunda sol elinin parmakları tamamen birleşmiş olup sağ el ise kısmen kullanılabilir durumdaydı. Tırnaklarda distrofi vardı (Resim 1). Hastada gelişim geriliği gözlenmiş olup kısa boy ve ekstremitelere sahipti. Hastanın ağız dışı muayenesinde sol kanin dişi hizasında ekstraoral abse gözlenmiştir (Resim 2). Hastanın ağız içi muayenesinde ağız hijyeninin çok kötü olduğu ve hastada mikrostomi mevcut olduğu için ağız açmada kısıtlıık gözlenmiştir (Resim 3). Hastadan alınan panaromik röntgende sol alt çenedeki kaninden kaynaklanan abse, alt ve üst çene arka bölgelerde kökler tespit edilmiştir (Resim 4). Öncelikle hastaya ağız hijyenin önemi anlatılarak ağız hijyeni uygulamaları öğretilmiştir. Küçük başlı, yumuşak diş fırçası ve ağız gargarası önerilmiştir. Mevcut hijyen iyileştirilmeye çalışılmışıı. Hastaya ve ailesine yapılacak tedavi anlatılarak Bilgilendirilmiş Onam Formu imzalatılış̧ıิı. Hastaya penisilin grubu bir antibiyotik reçete edilmiş, 1 hafta sonra ekstraoral abseye neden olan dişten başlanarak, diş çekimleri yapılmaya başlanmışır. Sol alt çenedeki kanin dişin çekimi yapıldıktan 1 hafta sonra ekstraoral absenin iyileştiği görülmüştür (Resim 5). Hastanın ağzında enfeksiyona neden olabilecek tüm dişlerin çekimi planlarak bir günde 2 diş çekimini geçmeyecek şekilde, haftada bir randevulara çağırımıştır. Epidermolozis bülloza hastalarında uygulanan diş tedavi protokollerine uyulmuş, tedavi öncesinde dudaklar vazelinlenmiştir. Çekim öncesi infiltratif lokal anestezi uygulanmıştı. Minimum travmayla, az basınç uygulanarak, atravmatik şekilde diş çekimleri gerçekleştirilmiştir. İşlem sırasında ağız içinde oluşan büller steril bir şekilde patlatılmışıı. Diğer dişlerin tedavileri İ.Ü. Diş Hastalıkları ve Tedavisi Anabilim Dalı'nda 2 seansta minimum travmayla yapılmıştır. Ağız hijyeni sorunsuz bir şekilde sağlanmış, hasta düzenli olarak 6 ayda bir kontrole çağrıımışıı. 1 yıl sonraki kontrolünde sağ kolunda sikatris bölgesinde squamous hücreli karsinom geliştiği öğrenilmiştir (Resim 6). Estetik ve Plastik Cerrahi kliniğinde sol kolun rezeksiyonuna karar verilmesine rağmen hasta ameliyatı kabul etmemektedir.

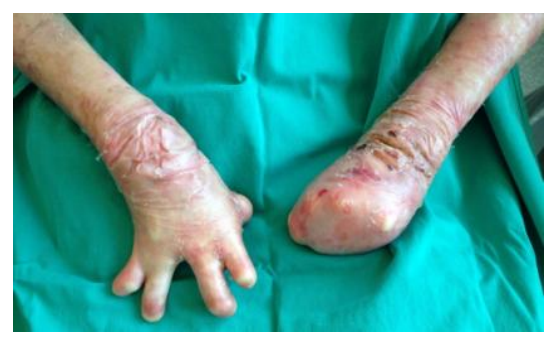

Resim 1. Hastanın ellerinin görüntüsü

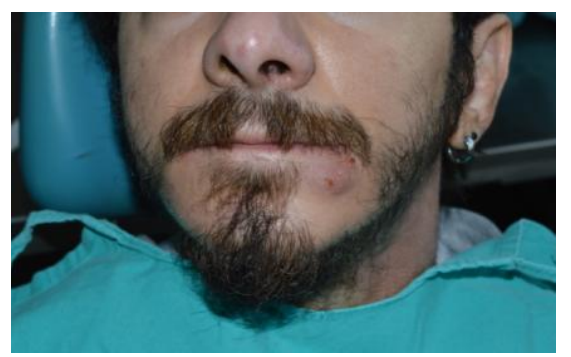

Resim 2. Sol alt kaninde kaynaklanan ekstraoral abse

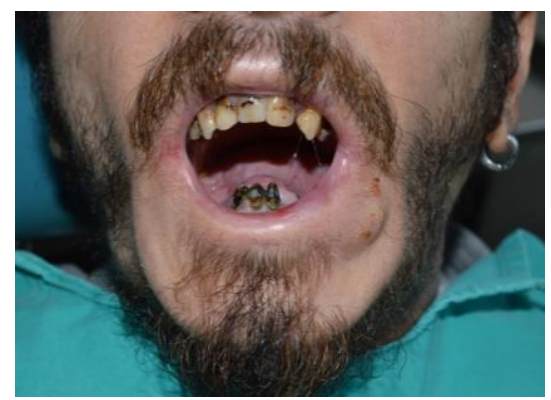

Resim 3. Mikrostomi ve abse nedeniyle ağız açmada kısıtııık 


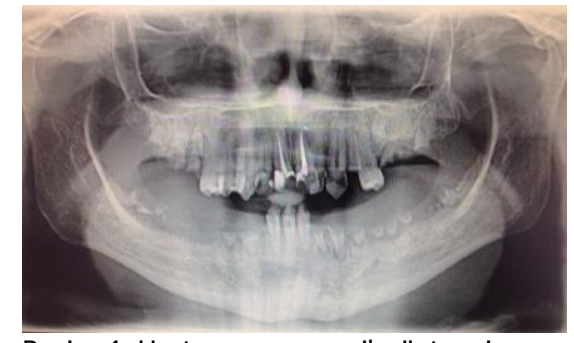

Resim 4. Hastanın panaromik röntgeni

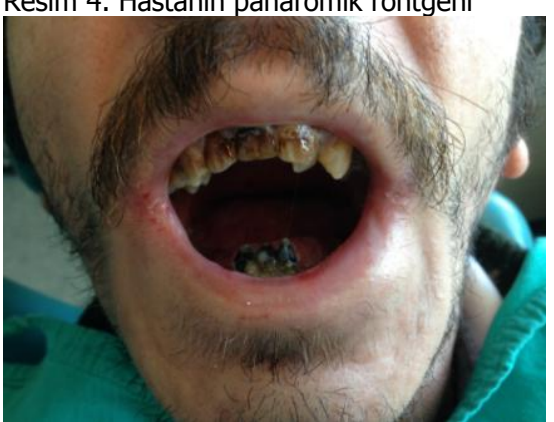

Resim 5. Sol alt kanin çekimi yapıldıktan ve abse iyileştikten sonraki hali

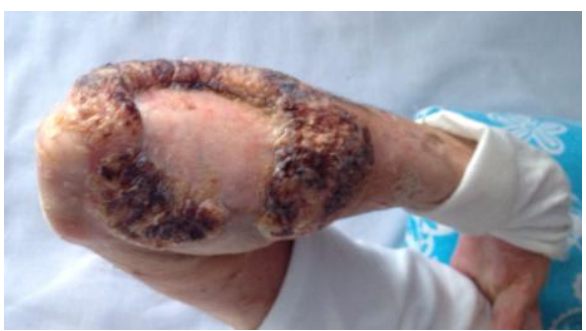

Resim 6. Hastanın sağ kolunda gelişen squamous hücreli karsinom (1 yıl sonra)

\section{TARTIŞMA}

EB; deri ve epitelyal yüzeyleri etkileyen, minör travma sonrasında intraepidermal büllerin oluşumuyla karakterize, bazı genlerde ortaya çıkan mutasyonlar sebebiyle görülen herediter bir hastalıktır. ${ }^{21}$ Deri ve müköz membranlarda büllerle birlikte erezyon ve kronik ülserlerle seyreder. EB olguları içinde \%5'lik bölümü oluşturan distrofik tip epidermolizis büllozada büller dermisin üstünde, lamina densanın altında yer alır. Bizim olgumuz da distrofik tip epidermolizis bülllozadır. Bu tipin görülmesinde, kollajen tip VII'nin kodlanmasından sorumlu olan COL7A1 geninin 3p21.31 kromozomunda görülen mutasyonlar etkilidir. ${ }^{21}$ Otozomal dominant ve resesif geçişli her iki tipinde de, ayrılma subepidermaldir. Anormal kollajenaz sentezinin sonucu olarak, bazal membranı dermise tespit eden bağlantılar yetersizdir. ${ }^{23}$
Hastalığın şiddetini, kollajen tip VII'de var olan mutasyonun tipi ve lokalizasyonu belirler. Kollajen tip VII, epidermis ve dermisteki bazal membran ve ekstrasellüler matriks yapımı ile ilgili birçok protein ile ilişkilidir. ${ }^{24} \mathrm{Bu}$ sebeple hastalık aynı mutasyona sahip olan monozigot ikizlerde bile, dermal fibroblastları farklı proteinlerin etkilemiş olması sebebiyle klinikte farklı şekil ve şiddetlerde seyredebilmektedir. ${ }^{25}$ Kollajen tip VII kaybı, dermal bölgede vasküler endotelyal faktör ve trombospondin miktarını ve dolayısıyla anjiyogenezi arttırır. Bu mekanizmanın aktive olmasıyla skuamoz hücreli karsinomun gelişimi ve ölümler tetiklenmiş olur. ${ }^{12}$ Bizim hastamızda da sağ kolunda skuamoz hücreli karsinom gelişmiştir.

EB tanısı klinik olarak ve cilt biyopsi materyalinin ışık mikroskopik, immünohistokimyasal ve elektron mikroskopik değerlendirilmesiyle yapılır. ${ }^{26}$ Deri lezyonları için ayırıcı tanıda konjenital ihtiyoziform eritrodermi, aplazia kutis konjenita, konjenital herpes simpleks virüs enfeksiyonu ve stafilokoksik soyulmuş deri sendromu akla gelmelidir. ${ }^{6}$ Oral bölge lezyonlarında kesin tanısı konulmamış hastalarda ise ayırıcı tanıda pemfigus, sikatrisyel ve büllöz pemfigoid, lineer IgA hastalığı düşünülmelidir. Bunların ayırıcı tanısı için klinik değerlendirme, histopatolojik, ışık, elektron ve immünfloresan inceleme ve kültür yöntemleri kullanılmaktadır. ${ }^{26}$

Büller genellikle travmaya maruz kalan bölgelerde görülür. Eller, ayaklar, dizler, dirsekler, kollar, saçlı deri bölgeleri ve sakrum sıklıkla büllerin görüldüğü bölgelerdir. ${ }^{27}$ Tırnaklarda distrofi sıklıkla gözlenir ve doğumda da görülebilir. Lezyonlar sikatrisyel değişiklikler bırakarak iyileşir. ${ }^{28}$ Kliniğimize başvuran hastada ise doğumdan sonra ilk dudak çevresinde soyulma şeklinde belirtiler görülmüş, takibinde ayak tabanları, kollar ve ellerde travmaya maruz kalan yerlerde büller oluşmuştur. İlerleyen dönemlerde hastanın ellerindeki tekrarlayan büller ve sikatrisler sonucunda sol elinin parmakları tamamen birleşmiş, sağ el ise kısmen kullanılabilir durumda kalmıştır.

Özellikle distrofik tip EB hastalarında diş çürüğü prevalansı artmıştır. Vakalarda minede hipoplazi de sıklıkla bildirilmiştir. Çürük riskinde artışın sebebi, hastaların beslenme şeklinin oral bölgelerdeki travmaları azaltmak amacıyla yumuşak ve karbonhidrattan zengin olmasıyla ilişkili olduğu düşünülmektedir. Ayrıca yumuşak doku bütünlüğünün bozulması, diş-diş eti uyumlarının kaybolması, dil ve yanak hareketlerinin sikatrisler 
sebebiyle azalması ve ağız hijyeninin sağlanmasındaki güçlükler de çürük riskinin artmasında etkilidir. ${ }^{29}$ Bizim olgumuzda da yaygın çürükler ve yetersiz ağız hijyeni gözlenmiştir.

EB'de sık görülen komplikasyonlar; ikincil yara enfeksiyonları, sepsis, pigmenter değişiklikler, el ve ayak parmaklarında yapışıkıklar, milia oluşumu, gelişme geriliği, anemi, kaşeksi, dolaşım yetersizliği, eklemlerde fleksiyon kontraktürleri, tırnak yitimleri, mukozal erozyonlar ve buna bağlı gastrointestinal motilite ve absorbsiyon bozuklukları, hastalı̆ın zemininde gelişebilen deri kanserleridir. ${ }^{4}$ Tırnak tutulumu distrofik tipe özgüdür ve kliniğimize başvuran hastada belirgin bir şekilde bulunmaktadır. EB hastalarında TME'nin etkilendiği ve ekstra artiküler ankilozun görüldüğü Rowe ve ark. tarafından bildirilmiştir. ${ }^{30}$ Bizim hastamızda ağız açmadaki kısıtlılığın sebebinin oral bölgedeki sikatrisler nedeniyle oluşan mikrostomia olduğu düşünülmektedir. İlerlemiş vakalarda skarlar mikroglossi ve ankiloglossiye sebep olabilmektedir. ${ }^{31}$ Dildeki papilların kaybolduğu da rapor edilmiştir. ${ }^{29}$ Squamous hücreli karsinom hastalarda bildirilen en ciddi komplikasyondur. Hastaların çoğunda erken yaşta en az bir bölgede squamous hücreli karsinom gelişmektedir ve agresif cerrahi eksizyon ile tedavi edildiğinde bile $\% 80$ hastada metastaz sebebiyle ölümler görülmektedir. ${ }^{32}$ Takip ettiğimiz hastada 1 yıl sonra sağ kolunda sikatris bölgesinde squamous hücreli karsinom gelişmiştir.

EB tam olarak tedavisi olmayan, sadece palyatif yaklaşımlar uygulanabilen, multidisipliner kontrollerle semptomları azaltılabilen bir hastalıktır. ${ }^{33}$ Hastalara proteinden zengin, demir ve çinko içerikli diyet önerilmektedir. Gelişen sekonder enfeksiyonlarda topikal veya sistemik antibiyotikler reçete edilmektedir. ${ }^{34}$

EB tedavisinde bazı moleküler terapi metodları deneysel olarak uygulanmaktadır. Gen terapisi çalışmalarında, retroviral bir vektör kullanılarak otolog keratinositler içine LAMB3 transgeni yerleştirilmiştir. 6 yllık kontrollerde dermal-epidermal bileşkede laminin332 salınımı izlenmiş ve deride mekanik travmalara karşı etkili bulunmuştur. ${ }^{33}$ Hücre bazlı çalışmalarda ise gen terapisine göre daha fazla ilerleme kaydedilmiştir. Intradermal olarak allojenik fibroblastların enjeksiyonu 9-12 aylık süreçlerde başarılı bulunmuştur. ${ }^{35}$ Intradermal olarak mezenkimal stromal hücrelerden elde edilen allojenik kemik iliği enjeksiyonunun 4 aylık süreçte başarılı olduğu rapor edilmiştir. ${ }^{36}$ Sistemik hücre terapisinde ise kemik iliği transplantasyonu uygulanan hastalar bulunmaktadır. Bu çalışmalar klinik araştırma olarak rapor edilmeye devam etmektedir. ${ }^{37}$ Eksik olan proteinlerin yerine konulması da tedavi şekli olarak düşünülmüş ve farelerde yapılan deneylerde Kollajen tip VII enjeksiyonu ile dermal-epidermal adezyon sağlanarak fibrin formasyonu görülmüştür. ${ }^{38}$ EB tedavisinde moleküler terapi yöntemleri umut vadedici olsa da bu konuda daha çok araştırmaya ihtiyaç vardır.

Dental tedavilerde ise koruyucu-önleyici yöntemlerin uygulanması önemli ve gereklidir. Diş hekimleri tarafından uygulanacak tedavilerde bül oluşmasına neden olmamak için atravmatik şekilde çalışılmalıdır. Sonrasında da bu hastalar çürük açısından risk grubunda oldukları için her 3-6 ayda bir diş hekimi kontrolü gereklidir. Genel anestezi bazı araştırmacılara göre intübasyon bölgelerinde faringeal ve trakeal bölgelerde bül oluşumu sebebiyle önerilmezken, bazı araştırmacllar bu bölgelerdeki bül oluşumunun oldukça nadir görülen bir komplikasyon olduğu görüşündedir. ${ }^{39}$ Bizim hastamızın diş tedavileri de lokal anestezi altında minimum travma ile yapılmıştır.

EB hastalarında hareketli protezler mukozal bölgelerde sebep olduğu minör travmalar sebebiyle tercih edilmemeli, sabit protezler ya da implant destekli sabit protezler tercih edilmelidir. EB hastalarında implant yapılan ve başarıı bulunan araştırmalar literatürde mevcuttur. EB hastalarında yapılan implant uygulamalarında \%97.7'ye varan oranlarda başarılar rapor edilmiştir. ${ }^{40}$ Penarrocha ve ark.'nın çalışmasında implant uygulması sırasında özel yöntemler uygulanmıştır. Önce mutlaka dudak ve perioral bölgede vazelin gibi bir lubrikant maddeler kullanılmışır. Operasyon sırasında insizyon ve flep aşamaları dahil olmak üzere sık sık serum fizyolojik ile irrigasyon uygulanmış ve oluşacak büllerin çevre dokuların infektif etkisinden uzaklaşııııması sağlanmıştır. İrrigasyon sırasında uygulanan aspirasyonda yumuşak doku temasından kaçınımışıtır. 1, 3, 6 ve 12 aylık kontrollerde implant çevresinde bül oluşumu, erozyon ve ülserasyonlar görülmemiştir. Radyografik kontrollerde implant çevresi kemik kaybı görülmemiştir. İmplant ve üstüne uygulanan sabit protezler düzenli olarak kontrol edilmiş, ağız içi yumuşak dokulara gelen minör travmaların uzaklaştıııması sağlanmıştır. Ayrıca kazandırılan çiğneme fonksiyonu sayesinde farinks ve larinks bölgelerindeki bül oluşumu riskleri azaltılmış ve hastalar için en önemli problemlerden biri olan 
beslenme fonksiyonu yerine getirilmiştir. ${ }^{40}$ CandelMarti ve ark.'nın çalışmasında ise toplam 16 hastada uygulanan 92 implant \%75-100 oranlarında başarılı olarak bildirilmiştir. ${ }^{41}$ Ancak epidermolizis büllozanın yara iyileşmesini etkilediği bilinmelidir. ${ }^{42}$

\section{SONUÇ}

Sonuç olarak EB, ciddi morbidite ve mortalite oranlarına sahip olan, hastaların yaşam kalitesinin çok büyük ölçüde azaldığı, kronik seyirli ve tam olarak tedavisi olmayan bir hastalıktır. Hastalar tedavi ve gelişebilecek komplikasyonlar açısından multidisipliner bir şekilde düzenli olarak takip edilmelidir.

\section{KAYNAKLAR}

1. Fine JD. Inherited epidermolysis bullosa: past, present, and future. Ann N Y Acad Sci 2010;1194:213-22.

2. Paller AS, Mancini AJ. Bullous disorders of childhood. Hurwitz Clinical Pediatric Dermatology. 4th ed. China: Elsevier Saunders; 2011. p. 303-13.

3. Karaduman A. Kalıtsal Büllü Hastalıklar (Inherited Bullous Diseases). Türkderm 2011; 45 Özel Sayı 2: 81-6.

4. Fine JD, Eady RA, Bauer EA, et al. The classification of inherited epidermolysis bullosa: Report of the Third International Consensus Meeting on Diagnosis and Classification of EB. J Am Acad Dermatol 2008;58:931-50.

5. Tidman MJ, Garzon MCG. Vesiculobullous Disease (Inherited Vesiculobullous Disease) Pediatric Dermatology. Eds. Schachner LA, Hansen RC. 3th ed. Edinburg, Mosby, 2003;683-94.

6. Fine JD. Inherited epidermolysis bullosa. Orphanet J Rare Dis 2010;5:12.

7. Fine DJ. Epidermolysis Bullosa . In: Bolognia JL, Jorizzo JL, Rapini RP et al : eds. Dermatology. 2 nd ed. İspanya: Mosby; 2008. p. 457-66.

8. Sprecher E. Epidermolysis Bullosa Simplex. Dermatol Clin 2010;28:23-32.

9. Horn HM, Tidman MJ. The clinical spectrum of dystrophic epidermolysis bullosa. $\mathrm{Br} \mathrm{J}$ Dermatol 2002;146:267-74.

10. Lai-Cheong JE, Tanaka A, Hawche G, et al. Kindler syndrome: a focal adhesion genodermatosis. $\mathrm{Br} \mathrm{J}$ Dermatol 2009;160:233-42.
11. Tosti A, de Farias DC, Murrell DF. Nail involvement in autoimmune bullous disorders. Dermatol Clin 2010;28:153-7.

12. Fine JD, Mellerio JE. Extracutaneous manifestations and complications of inherited epidermolysis bullosa: part I. Epithelial associated tissues. J Am Acad Dermatol 2009;61:367-84; quiz 385-6.

13. Fine JD, Mellerio JE. Extracutaneous manifestations and complications of inherited epidermolysis bullosa: part II. Other organs. J Am Acad Dermatol 2009;61:387-402; quiz 403-4.

14. Varki R, Sadowsky S, Pfendner E, Uitto J. Epidermolysis bullosa.I. Molecular genetics of the junctional and hemidesmosomal variants. J Med Genet 2006;43:450-7.

15. Varki R, Sadowski S, Uitto J, Pfendner E. Epidermolysis bullosa. II. Type VII collagen mutations and phenotype/genotype correlations in the dystrophic subtypes. J Med Genet 2007; 44: 181-92.

16. Trent JT, Kirsner RS. Epidermolysis bullosa: identification and treatment. Adv Skin Wound Care 2003; 16:284.

17. Ciccarelli AO, Rothaus KO, Carter DM, Lin AN. Plastic and reconstructive surgery in epidermolysis bullosa: Clinical experience with 110 procedures in 25 patient. Ann Plast Surg 1995; 35: 254.

18. Wright JT, Johnson LB, Fine JD. Development defects of enamel in humans with hereditary epidermolysis bullosa. Arch Oral Biol 1993;38:94555.

19. Saraçoğlu Tekin U, Güven O. Epidermolizis büllozada temporomandibular eklem bulguları (Symptoms of temporomandibular joint in epidermolysis bullosa). Turkiye Klinikleri J Dental Sci 2006:12.

20. Kramer SM, Serrano MC and et al. Oral health care for patients with epidermolysis bullosa-best clinical practice guidelines. Int J of Ped Dent 2012, 22: 135.

21. Odom RB, James WD, Berger TG. Some genodermatoses and acquired syndromes. In: Andrews' Diseases of The Skin. Clinical dermatology. 9th ed. Philadelphia: WB Saunders; 2000:p.682-732.

22. Christiano AM, Greenspan DS, Hoffman GG, Zhang $X$, Tamai $Y$, Lin AN, et al. A missense mutation in type VII collagen in two affected siblings with 
recessive dystrophic epidermolysis bullosa. Nat Ge net 1993;4:62-6.

23. Silva LC, Cruz RA, Abou-Id LR, Brini LN, Moreira LS. Clinical evaluation of patients with epidermolysis bullosa: review of the literature and case reports. Spec Care Dentist 2004;24:22-7.

24. Kuttner V, Mack C, Rigbolt KTG, Kern JS, Schilling $\mathrm{O}$, Busch $\mathrm{H}$, et al. Global remodeling of cellular microenvironment due to loss of collagen VII. Mol Syst Biol 2013:9:657.

25. Di Salvio M, Piccinni E, De Zenzo G et al. Diverse TGF-beta signaling in fibroblasts from phenotypically discordant monozygotic twins with recessive dystrophic epidermolysis bullosa. J Invest Dermatol 2012:132:90.

26. Jaunzems $A E$, Woods $A E$, Staples $A$. Electron microscopy and morphometry enhances differentiation of epidermolysis bullosa subtypes with normal values for 24 parameters in skin. Arch Dermatol Res 1997;289:631-9.

27. Demirçeken F, Okuyaz Ç, Zorlu P. Epidermolizis bülloza (Epidermolysis bullosa). Yeni Tıp Dergisi 2000;17:20-2.

28. Uitto J, Christiano AM. Inherited epidermolysis bullosa. Clinical features, molecular genetics, and pathoetiologic mechanisms. Dermatol Clin 1993;11:549-63.

29. Wright JT, Fine JD, Johnson L. Dental caries risk in hereditary epidermolysis bullosa. Pediatr Dent 1994;16:427-32.

30. Rowe NL, Sowray JH. Extra-articular ankyloses as a complication of dystrophic epidermolysis bullosa. $\mathrm{Br}$ J Oral Surg 1965:3: 136.

31. Serrano-Martínez MC, Bagán JV, Silvestre FJ, Viguer MT. Oral lesions in recessive dystrophic epidermolysis bullosa. Oral Dis. 2003;9:264-8.

32. Schwartz RA, Birnkrant AP, Rubenstein DJ, Kim U, Burgess GH, Stoll HL Jr., et al. Squamous cell carcinoma in dominant type epidermolysis bullosa dystrophica. Cancer 1981;47:615-20.

33. Ferrari S, Pellegrini G, Matsui T, Mavilio F, De Luca M. Gene therapy in combination with tissue engineering to treat epidermolysis bullosa. Expert Opin Biol Ther. 2006;6:367-78.

34. Hochberg MS, Vazquez-Santiago IA, Sher M. Epidermolysis bullosa: a case report. Oral Surg Oral Med Oral Pathol. 1993;75:54-7.

35. Nagy N, Almaani N, Tanaka A et al. HB- EGF induces COL7A1 expression in keratino- cytes and fibroblasts: possible mechanism underlying allogeneic fibroblast therapy in recessive dystrophic epidermolysis Bullosa. J Invest Dermatol 2011:131:1771-4.

36. Conget $\mathrm{P}$, Rodriguez $\mathrm{F}$, Kramer $\mathrm{S}$ et al. Replenishment of type VII collagen and reepithelialization of chronically ulcerated skin after intradermal administration of allogeneic mesenchymal stromal cells in two patients with recessive dystrophic epidermolysis bullosa. Cytotherapy 2010:12:429-31.

37. Wagner JE, Ishida-Yamamoto A, McGrath JA et al. Bone marrow transplantation for reces- sive dystrophic epidermolysis bullosa. N Engl J Med 2010:363:629-39.

38. Woodley DT, Wang X, Amir M et al. Intravenously injected recombinant human type VII collagen homes to skin wounds and restores skin integrity of dystrophic epidermolysis bullosa. J Invest Dermatol 2013:133:1910-3.

39. Iohom G, Lyons B. Anaesthesia for children with epidermolysis bullosa: a review of 20 years' experience. Eur J Anaesthesiol 2001;18:745-54.

40. Penarrocha M, Rambla J, Balaguer J, Serrano C, Silvestre J, Bagán JV. Complete Fixed Prostheses Over Implants in Patients With Oral Epidermolysis Bullosa. J Oral Maxillofac Surg 2007; Suppl 1: 65:103-6.

41. Candel-Marti E, Ata-Ali J, Peñarrocha-Oltra D, Peñarrocha-Diago M, Bagán JV. Dental implants in patients with oral mucosal alterations: An update. Med Oral Patol Oral Cir Bucal. 2011 Sep 1;16: e787-93.

42. Kutluay Köklü AH, Uğar Çankal DA. Yara İyileşmesini Etkileyen Faktörler İçerisinde Beslenmenin Yeri. J Dent Fac Atatürk Uni. 2013; Suppl 7: 135-41.

\section{Yazışma Adresi}

Dr. Özlem FİLİZ BAYAR

Site Mah. Sancar SK. No:39 D:50

Ümraniye/ İstanbul

TIf:0530 2083998

e-mail: ozlemflz@gmail.com 